\title{
ENTEROCOCCAL ISOLATES FROM RAW MILK AND DAIRY PRODUCTS IN RIYADH REGION AND THEIR SUSCEPTIBILITY TO COMMON ANTIBIOTICS
}

\author{
L. A. Nasser ${ }^{* 1}$, T. A. Elkersh ${ }^{2}$ and S. H. Mejally ${ }^{2}$ \\ ${ }^{1}$ Girl's College of Education, Riyadh, Saudi Arabia \\ ${ }^{2}$ Department of Clinical laboratory Sciences, College of Applied Medical Sciences, \\ King Saud University, Riyadh, Saudi Arabia
}

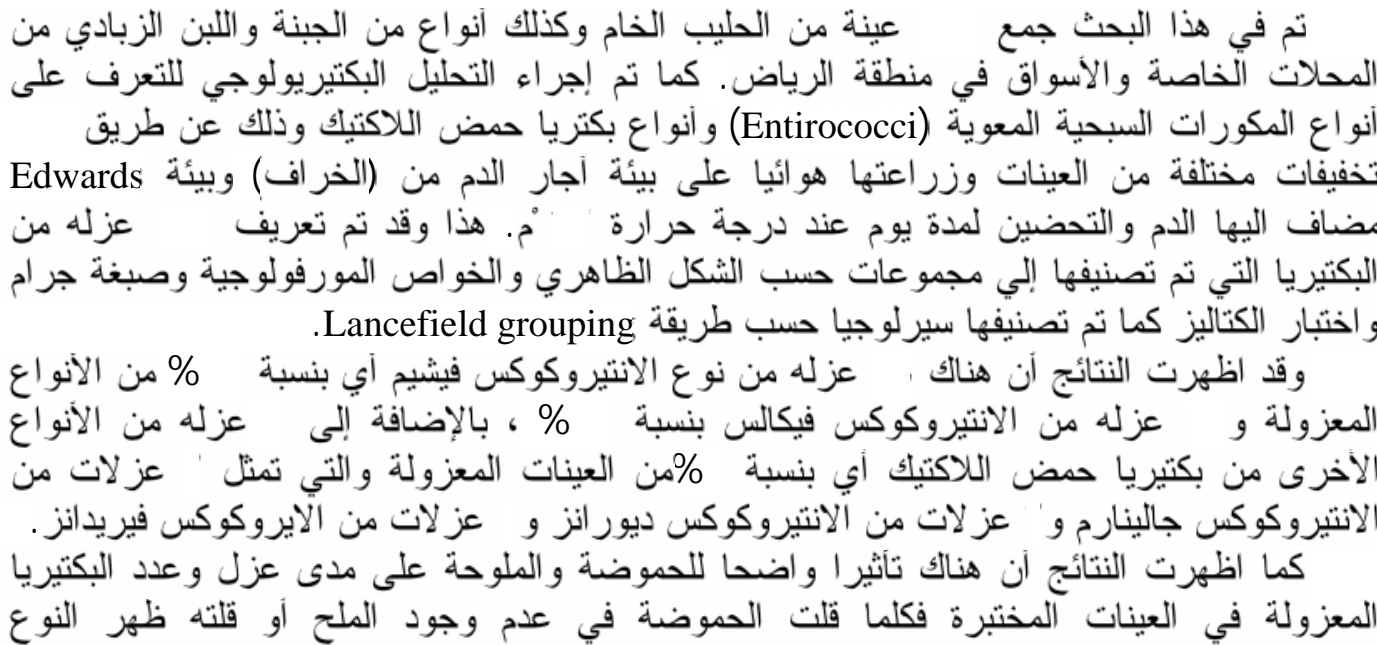
أنتيروكوكس فيكالس وبكتبريا حمض اللاكتيك بكثرة و العكس بالعكس.

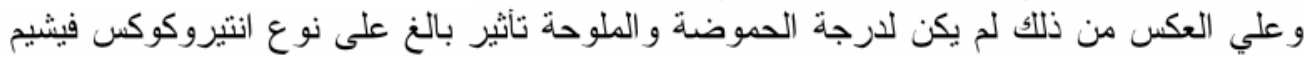

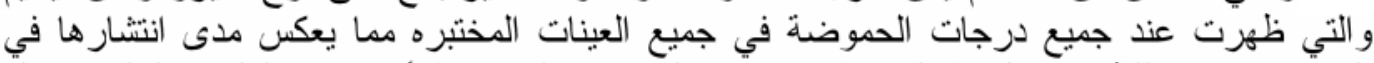

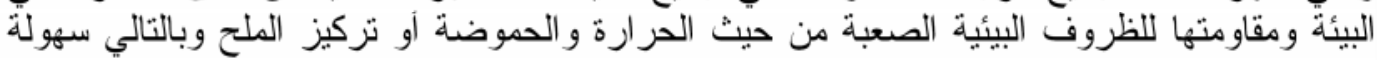

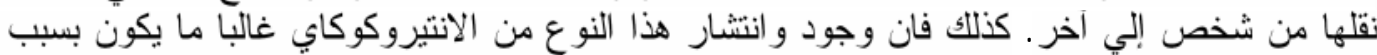

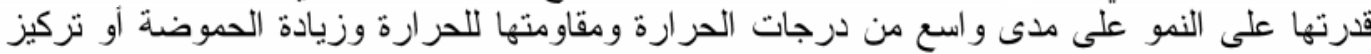

كذلك تم تقدير التزكيز المثبط (MIC) لعدد ومن المضادات الحيوية الثائعة لكل عزله من إجمالي

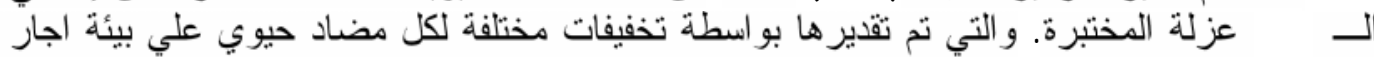
الام Muller Hinton.

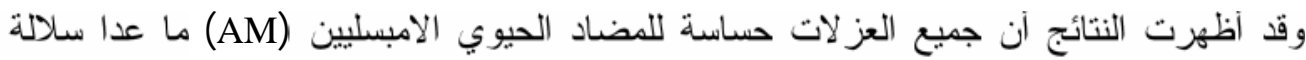
واحدة من الانتيروكوكس فيكالس. بينما اظهر مضاد اريثروميسين (EM) فاعلية جيده حيث كان التركيز

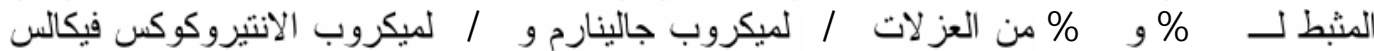

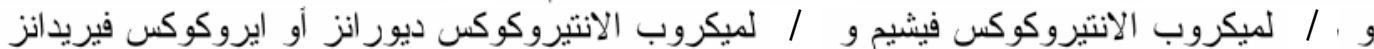

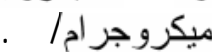

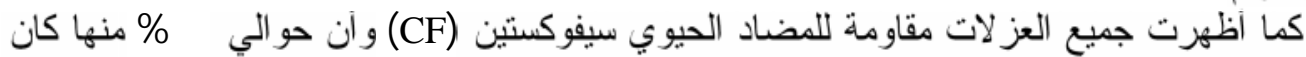

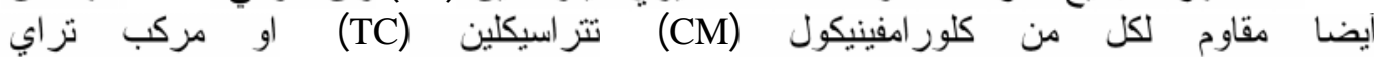

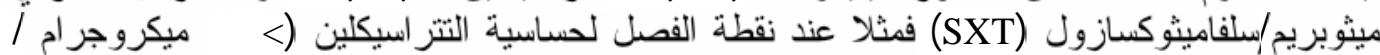

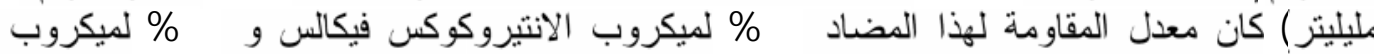

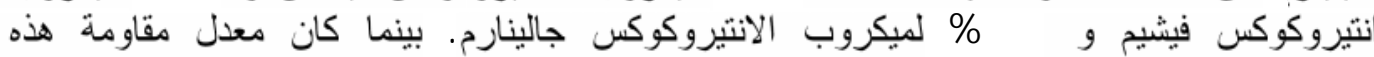

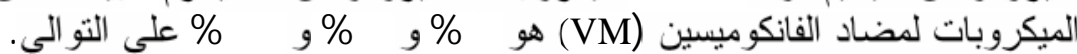

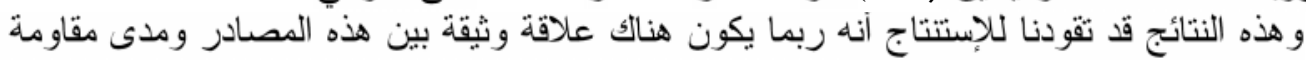
هذه الميكروبات للمضادات الحيوية في الإنسان. 
A total of 100 samples of raw milk, various cheeses, labnah, yogurt, and egett were collected from appropriate suppliers and markets in Riyadh region. Bacteriological analysis for typing of enterococci and other lactic Acid Bacteria (LAB) was carried out by plating appropriate dilutions of each sample on sheep blood agar and Edwards blood agar plates. After overnight aerobic incubation at $37^{\circ}$, the presumptive identification was done by colony morphology, cultural characteristics, Gram-stain and catalase production. Final identification to the genera and species level of the total 125 bacterial isolates was completed by API-20 strips as well as Lancefield-serogrouping. Results revealed that Enterococcus faecium (88 isolates) accounts of $70 \%$ of total bacterial isolates, while Enterococcus faecalis (26 isolates) accounts of up to $21 \%$ and other LAB constituted about $9 \%$ of total recovered isolates. The later isolates comprises 3, 3, and 5 isolates of Enterococcus gallinarum, Enterococcus durans, and Aerococcus viridans respectively.

The results revealed that nature of sample, its $\mathrm{pH}$, and salinity clearly affect the incidence and number of recovered bacterial isolates. Thus as $\mathrm{pH}$ rises towards neutrality, with no salt or low salinity, E. faecalis and other $L A B$ were recovered more frequently, and vice versa. In contrast, E. faecium was routinely isolated from most of the examined samples regardless of their $\mathrm{pH}$ range and salinity-content, reflecting its ubiquitous nature and its tolerance to drastic environmental conditions, thereby facilitating person to person transmission. The dominance or persistence of enterococci in examined samples is most probably attributed to their wide range of growth temperatures, their tolerance to heat, salt and acid.

In addition, the MIC of each of the tested 120 isolates was determined by serial dilution in Muller Hinton sheep blood agar against 9 antibiotics. All isolates were sensitive to ampicilin with the exception of one E. faecalis strain that showed an MIC of $4 \mathrm{ug} / \mathrm{ml}$. While Erythromycin (EM) exhibited also a good activity with an MIC50/MIC90 of 1/1, 1/4, 2/8 and 4/4 ug/ml. for E. gallinarum, E. faecalis, E. faecium, and E. durans or Aerococcus viridans isolates respectively. Whereas all isolates were resistant to cefoxitin and about 50\% were also resistant to Chloramphenicol (CM), Tetracycline (TC), or Trimethoprim / Sulfamethoxazole (SXT). Thus at the breakpoint of MIC (>16 ug/ml.) (TC) resistance rate for E. faecalis was $16 \%$ and for $E$. faecium and E. gallinarum was $35 \%$ and $100 \%$ respectively. Whereas that for vancomycin (VM) the figures were 44\%, 19\% and 100\% respectively. It is concluded that the examined samples may constitute a potential source for the dissemination of antibiotic resistant determinants to human.

\section{INTRODUCTION}

Many streptococci form part of the normal flora of humans and animals, and live harmlessly as commonsals while others may cause diseases in humans and animals. In traditional taxonomic schemes, the Streptococci belong to the family streptococcaceae. ${ }^{1}$ Lancefield ${ }^{2}$ detected a series of group of antigens that also made possible the sub classification of some streptococci. The antigens detected ${ }^{3}$ in the Lancefield grouping system are either cell wall polysaccharides (as in human group $\mathrm{A}, \mathrm{B}, \mathrm{C}, \mathrm{F}$, and $\mathrm{B}$ streptococcus species). On the other hand, enterococci are used as probiotics to improve the microbial balance of the intestine in humans and animals. ${ }^{3,4}$ In certain cheese, they are significant in repening and the development of flavor. ${ }^{5}$ Furthermore enterococci have emerged in recent years as pathogens in growing number of serious nosocomial infections including bacteremia and interabdominal and urinary tract infections. ${ }^{6}$ Accordingly, the present study was under taken to determine the species and incidence of enterococcal isolates and other lactic acid isolates from raw milk and dairy products and their susceptibility to common antibiotics.

\section{MATERIAL AND METHODS}

\section{Sampling}

A total of 100 different cheeses and raw milk samples were collected from various markets and farms in Riyadh city, Saudi Arabia. The samples were transferred to the laboratory and kept in refrigerator at $4^{\circ}$ till the bacterological analysis. The kind and number of raw milk or cheese samples as well as country of origin are shown in Table (1). 


\section{Bacterial isolates}

Samples of milk or cheese inquestion (10 $\mathrm{ml}$ or $10 \mathrm{gm}$ ) were aseptically homogenized in Todd-Hewitt (TW) broth $(90 \mathrm{ml})$ medium then incubated overnight at $37^{\circ}$. After incubation dilutions were made and subcultured on Blood agar and Edwards Blood agar (Oxiod, UK) media. The inoculated plates were then incubated aerobically at $37^{\circ}$ for 24 hours. ${ }^{7}$

Representative colonies were then purified by streaking on the same media and identified by convential cultural characteristics and identify confirmation by API-20 system according to El-Kersh et $\mathrm{al}^{7}$ and Facklam \& Gollins $^{8}$ as well as Lancefield serogrouping coagglantination tests (Denka Senka, Tokyo, Co. Ltd., Japan).

\section{Minmal Inhibitory Concentration (MICs) Of recovered bacterial isolates}

Minimal inhibitory concentrations (MICs) for nine antibiotics (AM, CH, GM, CL, VM, EM, SXT, TC, CF) were determined using two fold serial dilution of the antibiotics in Mueller-Hinton agar (Oxiod, UK) by the standard methods. ${ }^{9}$ The agar plates were inoculated using a multi-point inoculator (Denley, UK). Approximately $10^{4} \mathrm{CFU} /$ spot of the appropriately diluted overnight broth cultures were inoculated. Plates were incubated at $37^{\circ}$ for 18 hours. The MICs of the antibiotics were defined as the lowest concentration at which no growth was detected. Standard quality control strains (E. faecalis ATCC 29212, and S. aureus ATCC 29213) were included in each run. ${ }^{6}$

\section{RESULTS AND DISCUSSION}

The analysis of lactic acid bacterial isolates (LAB) from raw milk and dairy products revealed that the examined samples were rich with these isolates as expected. Thus a total of $125 \mathrm{LAB}$ isolates were recovered from the 100 samples tested and originated from local and foreign suppliers (Table 1). The isolate-presumptive identification was carried out by colony morphology, cultural characteristics, gram stain and catalase test. Lancsfield grouping and API identity confirmation results distinguished these isolates into $88 \mathrm{E}$. faecium, $26 \mathrm{E}$. faecalis, and 5, 3 and 3 isolates of Aerococcus viridans, E. gallinarum, and E. durans respectively (Table 2 ). These percentages of genera and species incidence may reflect their intrinsic tolerance towards variation in environmental conditions, and physiological capability of proteolysis activity, acid production from sugars, thereby $\mathrm{pH}$ variation, salt concentrations, as well as milk fat hydrolysis by esterase. ${ }^{10}$ The obtained results suggest that as $\mathrm{pH}$ rises toward neutrality, E. faecalis and other LAB were recovered more frequently and vice versa. This holds also true as the cheese salinity decreases. In contrast E. faecium was routinely isolated from most of the examined samples regardless of $\mathrm{pH}$ range and salt concentration.

The low incidence of E. faecalis recovery from raw milk despite its neutral $\mathrm{pH}$, (only one isolate from 24 samples) may suggest the good hygienic measures of raw milk handling in Saudi Arabia.

It should be mentioned, that enterococci exhibit higher proteolysis activity than other $\mathrm{LAB}$ and this is considered important for cheese ripening aroma. ${ }^{11}$ Similarly E. durans was also shown to be important for aroma development in Feta cheese. ${ }^{12}$ Obviously enterococci and other LAB play an important role in the manufacture of cheese typical of some regions and their use impact on this part of the dairy-industry. The dominance or persistence of enterococci in tested dairy product samples can be attributed to their wide range of growth temperatures, their high tolerance to heat, salt and acids. ${ }^{10}$

The MICs required to inhibit 50\% $\left(\mathrm{MIC}_{50}\right)$ and $90 \%\left(\mathrm{MIC}_{90}\right)$ of the tested 120 isolates and their respective resistance $(\%)$ to the tested antibiotics are listed in Table (3). All bacterial isolates were sensitive to the beta lactam AP with the exception of one E. faecalis strain that exhibited an elevated MIC of $4 \mathrm{ug} / \mathrm{ml}$. Most isolates showed moderate to high resistance toward CL, but comparatively good susceptibility towards EM with an $\mathrm{MIC}_{50} / \mathrm{MIC}_{90}$ range of $1 / 1 \mathrm{ug} / \mathrm{ml}$ to $2 / 8 \mathrm{ug} / \mathrm{ml}$. These findings are in general agreement with those previously reported, ${ }^{13,14}$ from USA and UK respectively; but lower than those of a local study ${ }^{6}$ in Saudi Arabia where EM exhibited poor activity with a resistance rate of $44 \%$ against clinical enterococcal isolates. Table (3) also shows that 
Table 1: Kind and number of raw milk, cheese samples and country of origin.

\begin{tabular}{|c|c|c|c|c|}
\hline No. & Type of cheese & No. of & \multicolumn{2}{|c|}{ Producing Country } \\
\hline 1 & Raw Milk & 24 & Saudi Arabia & $(24)$ \\
\hline 2 & White Cheese & 12 & $\begin{array}{l}\text { Denmark } \\
\text { Bulgaria } \\
\text { Hangaria } \\
\text { Turkey } \\
\text { Egypt } \\
\text { France } \\
\text { Germany }\end{array}$ & $\begin{array}{l}(4) \\
(2) \\
(2) \\
(1) \\
(1) \\
(1) \\
(1)\end{array}$ \\
\hline 3 & White Cheese (Low Salt) & 12 & $\begin{array}{l}\text { Egypt } \\
\text { Saudi Arabia } \\
\text { Denmark } \\
\text { Bulgaria } \\
\text { Greece } \\
\text { Hangaria } \\
\text { France } \\
\end{array}$ & $\begin{array}{l}(5) \\
(2) \\
(1) \\
(1) \\
(1) \\
(1) \\
(1)\end{array}$ \\
\hline 4 & Cream Cheese (Double) & 11 & $\begin{array}{l}\text { Egypt } \\
\text { Denmark } \\
\text { Hangaria } \\
\text { France } \\
\text { Hungary } \\
\end{array}$ & $\begin{array}{l}(7) \\
(1) \\
(1) \\
(1) \\
(1)\end{array}$ \\
\hline 5 & Labnah & 8 & $\begin{array}{l}\text { Saudi Arabia } \\
\text { Turkey } \\
\text { Egypt } \\
\text { France } \\
\text { Lebanon } \\
\end{array}$ & $\begin{array}{l}(3) \\
(2) \\
(1) \\
(1) \\
(1)\end{array}$ \\
\hline 6 & Fresh Cream & 6 & $\begin{array}{l}\text { Saudi Arabia } \\
\text { Egypt }\end{array}$ & $\begin{array}{l}(5) \\
(1) \\
\end{array}$ \\
\hline 7 & White Cheese (Domyati) & 4 & Egypt & (4) \\
\hline 8 & White Cheese (Hallom) & 3 & $\begin{array}{l}\text { Syria } \\
\text { Saudi Arabia } \\
\end{array}$ & $\begin{array}{l}(2) \\
(1) \\
\end{array}$ \\
\hline 9 & White Cheese (Arish) & 3 & Egypt & (3) \\
\hline 10 & White Cheese (Akawi) & 2 & $\begin{array}{l}\text { Syria } \\
\text { Egypt }\end{array}$ & $\begin{array}{l}(1) \\
(1) \\
\end{array}$ \\
\hline 11 & $\begin{array}{l}\text { White Cheese (Akawi Free } \\
\text { Salt) }\end{array}$ & 2 & $\begin{array}{l}\text { France } \\
\text { Syria } \\
\end{array}$ & $\begin{array}{l}(1) \\
(1) \\
\end{array}$ \\
\hline 12 & White Cheese (Feta) & 2 & $\begin{array}{l}\text { Denmark } \\
\text { France }\end{array}$ & $\begin{array}{l}(1) \\
(1) \\
\end{array}$ \\
\hline 13 & White Cheese (Bader) & 2 & Egypt & $(2)$ \\
\hline 14 & White Cheese (Low Fat) & 2 & $\begin{array}{l}\text { Holland } \\
\text { Denmark } \\
\end{array}$ & $\begin{array}{l}(1) \\
(1) \\
\end{array}$ \\
\hline 15 & Yogurt & 2 & Saudi Arabia & $(2)$ \\
\hline 16 & White Cheese (Free Salt) & 1 & Denmark & $(1)$ \\
\hline 17 & White Cheese (Free Fat) & 1 & Denmark & $(1)$ \\
\hline 18 & White Cheese (Shillal) & 1 & Syria & $(1)$ \\
\hline 19 & $\begin{array}{l}\text { White Cheese (Akawi Low } \\
\text { Salt) }\end{array}$ & 1 & France & (1) \\
\hline 20 & Egett & 1 & Saudi Arabia & $(1)$ \\
\hline Total & & 100 & & \\
\hline
\end{tabular}


Table 2: Raw milk and dairy product, $\mathrm{pH}$ range, number of bacterial isolates and $\%$ of total species.

\begin{tabular}{|c|c|c|c|c|}
\hline Kind of cheese & $\mathrm{pH}$ rang & Bacterial Isolates & $\begin{array}{l}\text { No. of } \\
\text { isolates }\end{array}$ & $\begin{array}{l}\% \text { of the } \\
\text { species }\end{array}$ \\
\hline Raw Milk (24 samples) & 7 & $\begin{array}{l}\text { E. faecium } \\
\text { E. faecalis } \\
\text { Aerococcus viridans }\end{array}$ & $\begin{array}{c}21 \\
1 \\
1\end{array}$ & $\begin{array}{c}24 \\
3 \\
20\end{array}$ \\
\hline White cheese (12) & $5 \rightarrow 6$ & $\begin{array}{l}\text { E. faecium } \\
\text { E. faecalis } \\
\text { E. gallinarum } \\
\end{array}$ & $\begin{array}{c}15 \\
2 \\
2 \\
\end{array}$ & $\begin{array}{c}17 \\
8 \\
67 \\
\end{array}$ \\
\hline White cheese (Low salt) (12) & $5 \rightarrow 7$ & $\begin{array}{l}\text { E. faecium } \\
\text { E. faecalis } \\
\text { E. durans }\end{array}$ & $\begin{array}{c}10 \\
4 \\
1\end{array}$ & $\begin{array}{l}11 \\
15 \\
33\end{array}$ \\
\hline White cheese (Double) (11) & $5 \rightarrow 6.5$ & $\begin{array}{l}\text { E. faecium } \\
\text { E. faecalis } \\
\text { E. gallinarum }\end{array}$ & $\begin{array}{l}7 \\
3 \\
1\end{array}$ & $\begin{array}{c}8 \\
11 \\
33\end{array}$ \\
\hline Labnah (8) & $4 \rightarrow 5.5$ & $\begin{array}{l}\text { E. faecium } \\
\text { E. faecalis } \\
\end{array}$ & $\begin{array}{l}9 \\
2 \\
\end{array}$ & $\begin{array}{c}10 \\
8 \\
\end{array}$ \\
\hline Fresh Cream (5) & $6 \rightarrow 7$ & $\begin{array}{l}\text { E. faecium } \\
\text { E. faecalis } \\
\text { E. durans } \\
\text { Aerococcus viridans }\end{array}$ & $\begin{array}{l}2 \\
4 \\
1 \\
1\end{array}$ & $\begin{array}{c}2 \\
15 \\
33 \\
20\end{array}$ \\
\hline White cheese (Domyati) (4) & $4 \rightarrow 6.5$ & $\begin{array}{l}\text { E. faecium } \\
\text { E. faecalis } \\
\text { Aerococcus viridans }\end{array}$ & $\begin{array}{l}5 \\
1 \\
1\end{array}$ & $\begin{array}{c}6 \\
4 \\
20\end{array}$ \\
\hline White cheese (Hallom) (3) & $6 \rightarrow 5.7$ & $\begin{array}{l}\text { E. faecium } \\
\text { E. faecalis }\end{array}$ & $\begin{array}{l}4 \\
1 \\
\end{array}$ & $\begin{array}{l}4 \\
4 \\
\end{array}$ \\
\hline White cheese (Arish) (3) & $4 \rightarrow 4.5$ & $\begin{array}{l}\text { E. faecium } \\
\text { E. faecalis } \\
\text { E. durans } \\
\end{array}$ & $\begin{array}{l}2 \\
1 \\
1 \\
\end{array}$ & $\begin{array}{c}2 \\
4 \\
33 \\
\end{array}$ \\
\hline White cheese (Akawi) (2) & 7 & $\begin{array}{l}\text { E. faecalis } \\
\text { Aerococcus viridans }\end{array}$ & $\begin{array}{l}2 \\
1\end{array}$ & $\begin{array}{c}8 \\
20\end{array}$ \\
\hline White cheese (Akawi Low Salt) (1) & 6 & E. faecium & 3 & 3 \\
\hline White cheese (Akawi Free Salt) (2) & $5 \rightarrow 6.5$ & $\begin{array}{l}\text { E. faecium } \\
\text { E. faecalis }\end{array}$ & $\begin{array}{l}1 \\
1 \\
\end{array}$ & $\begin{array}{l}1 \\
4 \\
\end{array}$ \\
\hline White cheese (Feeta) (2) & $5 \rightarrow 6$ & E. faecium & 2 & 2 \\
\hline White cheese (Bader) (2) & 5 & $\begin{array}{l}\text { E. faecium } \\
\text { E. faecalis }\end{array}$ & $\begin{array}{l}2 \\
1 \\
\end{array}$ & $\begin{array}{l}2 \\
4 \\
\end{array}$ \\
\hline White cheese (Low fat) (2) & $6 \rightarrow 6.5$ & $\begin{array}{l}\text { E. faecium } \\
\text { E. faecalis }\end{array}$ & $\begin{array}{l}1 \\
1 \\
\end{array}$ & $\begin{array}{l}1 \\
4 \\
\end{array}$ \\
\hline Yogurt (2) & 4 & E. faecium & 2 & 2 \\
\hline White cheese (Free salt) (1) & 7 & E. faecium & 1 & 4 \\
\hline White cheese (Free Fat) (1) & 5 & E. fecalis & 1 & 4 \\
\hline White cheese (Shillal) (1) & 5 & $\begin{array}{l}\text { E. fecalis } \\
\text { Aerococcus viridans }\end{array}$ & $\begin{array}{l}1 \\
1 \\
\end{array}$ & $\begin{array}{c}4 \\
20 \\
\end{array}$ \\
\hline Egett (1) & 5 & E. faecium & 1 & 1 \\
\hline
\end{tabular}


Table 3: Minimum inhibitory concentrations of antibiotics against recovered bacterial isolates.

\begin{tabular}{|c|c|c|c|c|c|c|c|c|c|}
\hline \multirow{2}{*}{$\begin{array}{c}\text { Type of bacteria } \\
\text { isolates (No.) }\end{array}$} & \multicolumn{9}{|c|}{$\mathrm{MIC}_{50} / \mathrm{MIC}_{90}$ Antibiotics $*$ in $\mathrm{Mg} /$ Liter $(\mathrm{R} \%)$} \\
\hline & AP & $\mathrm{CL}$ & $\mathrm{CM}$ & EM & GM & VM & SXT & $\mathrm{TC}$ & $\mathrm{CF}$ \\
\hline E. faecium (85) & $(0.0)$ & (45) & (44) & (31) & (26) & (19) & (38) & (35) & (100) \\
\hline $\mathrm{MIC}_{50}$ & 1 & 1 & 4 & 2 & 8 & 2 & 2 & 4 & $\leq 8$ \\
\hline $\mathrm{MIC}_{90}$ & 1.5 & 8 & 8 & 8 & 16 & 8 & 8 & 64 & $\leq 8$ \\
\hline E. faecalis (25) & (4) & $(72)$ & $(44)$ & $(28)$ & $(16)$ & (44) & $(24)$ & $(16)$ & $(100)$ \\
\hline $\mathrm{MIC}_{50}$ & 1 & 8 & 4 & 1 & 4 & 4 & 1 & 4 & $<8$ \\
\hline $\mathrm{MIC}_{90}$ & 2 & 8 & 8 & 4 & 16 & 16 & 4 & 64 & $<8$ \\
\hline E. gallinarum (3) & $(0.0)$ & $(100)$ & $(100)$ & $(0.0)$ & $(0.0)$ & $(100)$ & $(100)$ & $(100)$ & $(100)$ \\
\hline $\mathrm{MIC}_{50}$ & 0.5 & 8 & 8 & 1 & 4 & 16 & 8 & 64 & $>8$ \\
\hline MIC $_{90}$ & 1 & 8 & 8 & 1 & 4 & 16 & 8 & 64 & $>8$ \\
\hline E. durans (3) & $(0.0)$ & $\begin{array}{l}(0.0) \\
\end{array}$ & (66) & (66) & $\begin{array}{l}(0.0) \\
\end{array}$ & $(0.0)$ & (66) & $(0.0)$ & (100) \\
\hline $\mathrm{MIC}_{50}$ & 0.5 & 1 & 8 & 4 & 8 & 2 & 8 & $\leq 4$ & $>8$ \\
\hline $\mathrm{MIC}_{90}$ & 1 & 1 & 8 & 4 & 8 & 2 & 8 & $\leq 4$ & $>8$ \\
\hline $\begin{array}{l}\text { Aerococcus } \\
\text { Viridans (4) }\end{array}$ & $(0.0)$ & $(100)$ & (100) & (75) & $(0.0)$ & $(0.0)$ & $(0.0)$ & $(0.0)$ & (100) \\
\hline $\mathrm{MIC}_{50}$ & 1 & 8 & 8 & 4 & 8 & 4 & $\leq 1$ & $\leq 4$ & $>8$ \\
\hline $\mathrm{MIC}_{90}$ & 1 & $>8$ & 8 & 4 & 8 & 4 & $\leq 1$ & $\leq 4$ & $>8$ \\
\hline
\end{tabular}

*The breakpoints (ug / ml): Ampicillin (AP), $\leq 0.25 \geq 4$; Erythromycin (EM) and Clindamycin (CL) $\leq$ $1 \geq 4$; Gentamicin (GM) and Tetracycline (TC), $\leq 8 \geq 16$; Vancomycin (VM) and Chloramphenicol $(\mathrm{CM}), \leq 4 \geq 8$; Cefoxitin (CF), $\leq 1 \geq 8$; Trimethoprim / Sulfamethoxazole (SXT), $\leq 2 \geq 4$.

GM exhibited an $\mathrm{MIC}_{50} / \mathrm{MIC}_{90}$ range of $4 / 4$ $\mathrm{ug} / \mathrm{ml}$ to $8 / 16 \mathrm{ug} / \mathrm{ml}$ for the tested isolates and none of the isolates exhibited high-level $(>2000 \mathrm{ug} / \mathrm{ml})$ of $\mathrm{GM}$ resistance. All isolates, however were resistant to $\mathrm{CF}$ as judged by the breakpoint of susceptibility (MIC $<8 \mathrm{ug} / \mathrm{ml})$.

In agreement with Warren $^{16}$ chloramphenicol exhibited a resistance rate of $44 \%$ for both E. faecium and E. faecalis, but with increased resistance rates against other LAB isolates, with $66 \%$ resistance for $E$. durans and $100 \%$ for Aerococcus viridans or $E$. gallinarum. This may be attributed to the extensive use of this drug and its congers in animal husbandries. ${ }^{5}$ This holds also true for SXT combination ${ }^{6}$ and TC which showed full resistance $(100 \%)$ against $E$. gallarinum Boyce ${ }^{17}$ demonstrated a progressive increase in resistance to TC among enterococci between 1990 and 1992.

It is evident also from Table (3) that in general, E. faecium was more resistant to most of the tested antibiotics with the exception of $\mathrm{VM}$ and AP which showed less activity against
E. faecalis. The resistance percentages of both drugs were $19 \& 0.0 \%$ for E. faecium and $44 \&$ $4 \%$ for E. faecalis respectively. Their $\mathrm{MIC}_{50} / \mathrm{MIC}_{90}$ against E. faecium were $1 / 1.5$ and $2 / 8 \mathrm{ug} / \mathrm{ml}$, whereas those for $E$. faecalis were $1 / 2$ and $4 / 16 \mathrm{ug} / \mathrm{ml}$ respectively. High susceptibilities (90\% and 100\%) to AP were also demonstrated from different places. ${ }^{14,18} \mathrm{On}$ the other hand, resistance rates as high as $75 \%$ to AP were reported from a study from France between 1985and 1993. ${ }^{19}$

The obtained rate of VM resistance (breakpoint $>16 \mathrm{ug} / \mathrm{ml}$ ) appears to be higher than those of previous local studies on clinical isolates of entrococci of Al-Auaji et al. ${ }^{6}$ and Qadri et al. ${ }^{20}$ with resistance rates to $\mathrm{VM}$ of 11 and 3\% respectively, but comparable resistance rates, were also demonstrated in other studies. $^{21,22}$

It should be emphasized that vancomycin resistant enterococci (VRE) are also highly resistant to all standard anti-enterococcal drugs, including penicillin-aminoglycoside combinations, leaving only a few alternatives for 
successful treatment. The VRE are therefore considered as a serious risk group among bacterial nosocomial pathogens. ${ }^{5,6}$

Furthermore, E. faecalis accounts of 85$90 \%$ of the clinical entrococcal isolates, and $E$. faecium and other species represent 5-10\% and not more than $5 \%$ respectively. ${ }^{23,24,25-32}$ This situation is complicated by the fairly common trait of transferable drug resistance within the two enterococcal species, which may confer resistance especially the acquired resistance phenotypes (Van A \& B) to glycopeptides (VRE) are transferable by conjugation. ${ }^{15}$

The importance of VRE in nosocomial disease, therefore, cannot be disregarded. Although E. faecalis seems to have a greater pathogenic potential than E. faecium, the association of either of these species with food may not be considered desirable. ${ }^{10}$

\section{REFERENCES}

1- J. G. Holt, N. R. Kreig, P. H. Sneath, J. T. Staley and S. T. Williams, Gram Positive cocci, In: J. G Holt, N. R. Kreig, P. H. Sneath, J. T. Staley, S. T. Williams Steds. Bergey's Manual of Determinative Bacteriology, $9^{\text {th }}$ ed. Baltimore: Williams and Wilkins Co., 5 1994, pp. 27-558.

2- R. C. Lancefield, J. Exp. Med., 47, 91-103 (1928).

3- E. Bingen, E. Denamur, N, J. Infect. Dis., 165, 569-573 (1992).

4- P. Poulain, P. Betremieux, P. Y. Donnio, J. F. Proudhon, G. Karege and J. R. Girayd, Euro. J. Obstet. Gynecol. and Reproductive Biology, 72, 137-140 (1997).

5- T. J. Eaton and M. J. Gasson, Applied and Environmental Microbiology, 67, 16281635 (2001).

6- A. A. Al-Auaji, F. M. Mustafa, T. A. ElKersh and F. J. Al-Shammary, Saudi Pharmaceutical Journal, 8, 43-50 (2000).

7- T. A. El-Kersh, L. A. Al-Nuaim, T. A. Kharfy, F. J. Al-Shammary, S. S. Al-Saleh and F. A. Al-Zamel, Saudi Med. J., 23, 5661 (2002).

8- K. R. Facklam and M. D. Gollins, J. Clin. Microbiol., 27, 731-4 (1989).

9- National Committee for Clinical Laboratory Standards Methods for Dilution Antmicrobial Susceptibility Tests for Bacteria that Grow Aerobically. Approved Standard M7-A3 National Committee for Clinical Laboratory Standards, Villanova Pa (1993).

10- C. M. A. P. Franz, W. H. Holzapfel and M. E. Stiles, International Journal of Food Microbiology, 47, 124-145 (1999).

11- J. A. Centeno, S. Menendez and J. L. Rodriguez-Otero, Int. Food Microbiol., 33, 307-313 (1996).

12- E. Litopoulou-Tzanetaki, N. Tzanetakis and A. Vafopoulou-MastroJianaki, Food Microbiology, 10, 31-41 (1993).

13- M. J. Kim, M. Weiser, S. Gottschall and E. I. Randall, J. Clin Microbial., 25, 78790 (1987).

14- J. W. Gray, D. Stewart and S. J. Pedler, Antimicrob. Agents Chemother., 35, 19435 (1991).

15- M. Shiojima, H. Tomita, K. Tanimoto, S. Fujimoto and Y. Ike, Antimicrob. Agents Chemother., 41, 702-5 (1997).

16- R. E. Warren RE, J. Hosp. Infect., 11 (Suppl. A), 352-7 (1988).

17- J. M. Boyce, S. M. Opal, G. PotterBynone, R. G. Laforge, M. J. Zervos, G. Futado, G. Victor and A. A. Medeiros, Antimicrob, Agents Chemother., 36, 10329 (1992).

18- S. C. Predari, M. A. Gutierrez, C. Ribas, G. S. Molinari and J. E. Santoianni, Revista Argentina le Microbiologia., 23, 67-78 (1991).

19- F. Bentrocha, F. Delbos and T. Horaud, Adv. Exp. Med. Biol., 418, 487-9 (1997).

20- S. M. H. Qadri, Y. Heno, A. G. Postle and B. A. Cunha, Annals of Saudi Medicine, 16, 377-80 (1996).

21- R. Leclercq, Clin. Infect. Dis., 24 (Suppl 1), S80- S84 (1997).

22- J. F. Boyle, S. A. Soumakis, A. Rendo, J. A. Herrington, D. G. Gianarkis, B. E. Tharberg and B. G. Painter, J. Clin. Microbiol., 31, 1280-5 (1993).

23- S. Gordon, S. M. Swenson, B. C. Hill, N. E. Opigott, R. R. Facklam, R. C. Cooksey, C. Thornsberry, W. R. Jaris and F. R. Tenover, J. Clan Microbiol., 3, 2373-8 (1992).

24- M. Straut, G. de Cespedes and T. Horaud, Antimicrob. Agents Chemother., 40, 12635 (1996). 
25- E. Markopulos, W. Graninger and A. Geogopouls, J. Antimicrob. Agents Chemother., 41, 43-7 (1998).

26- S. Simijee and M. J. Gill, J. Hosp. Infect., 36, 249-59 (1997).

27- K. L. Ruoff, Streptococcus. In: P. R. Murray, E. J. Baron, M. A. Pfaller, F. C. Tenover and R. H. Yolken, (eds). Manual of Clinical Microbiology, Washinton D.C., American Society for Microbiology, 1995, pp. 229-307.

28- J. W. Chow, A. Kuritza, D. M. Shlaes, M. Green, D. F. Sahm and M. J. Zervos, J. Clin. Microbiol., 31, 1609-11 (1993).
29- R. C. Jr. Moellering, Clin. Infect. Dis., 14, 1173-8 (1992).

30- D. G. Maki and W. A. Agger, Enterococcal Bacteremia: Clinical Features, the Risk of Endocarditis, and Management. Medicine (Baltimore), 67, 1988, pp. 248-69.

31- D. M. Shlaes, J. Levy and E. Wolinsky, Arch. Inten. Med., 141, 578-81 (1981).

32- N. E. Reiner, K. V. Gopalakrishna and P. I. Lerner, J. Am. Med. Assoc., 235, 1861-3 (1981). 